\title{
Lowbrow culture and French cultural policy: the socio-political logics of a changing and paradoxical relationship
}

Vincent Dubois, Professor of sociology and political science, University of Strasbourg and Institut universitaire de France, GSPE-PRISME (UMR 7012).

MISHA - 5, Allée du Général Rouvillois CS 50008 - F-67083 Strasbourg cedex France +33(0)368 856170 vincent.dubois@ misha.fr

Biography: Vincent Dubois is a sociologist and political scientist, specialising in cultural policy. He has published widely on the topic, including two papers in the International Journal of Cultural Policy and several books (in French). His current research areas include: Sociology of folk music (the case of brass bands); cultural managers; local cultural policies; language policy in France; and policies against welfare fraud.

\begin{abstract}
The polysemy of the phrase cultures populaires reflects the struggles to define the relationship between culture and the people in France. This paper displays the variety of the social and political uses of this phrase and recalls the issues it raises. It also explains the ambiguities of cultural policy programmes towards 'low' culture, most of these programmes remaining oriented in a culturally legitimist approach even when they try to promote alternative forms of culture.
\end{abstract}

Keywords: French cultural policy; cultural hierarchy; low culture. 


\section{Lowbrow culture and French cultural policy: the socio-political logics of a changing and paradoxical relationship}

\section{Introduction}

Lawrence Levine has shown in his seminal book on the American case that we must not regard the categories we use to classify cultural forms as neutral, trans-historical descriptions of aesthetic contents. Rather, these categories are the result of an antagonistic socio-historical process of hierarchisation in which social groups and professions define their social status together with the value and significance of cultural goods (Levine 1990). Levine's historical contribution can to some extent be combined with Bourdieu's sociological analysis of the distinctive uses of cultural hierarchies (Bourdieu, 1984). The two authors show the arbitrariness of these hierarchies and their double relationship with social structure as both products and symbols of class hierarchies. By doing so they remind us that judgements about 'low', 'popular' or 'indigenous' cultural forms are never a matter of 'pure' taste, whether they be critical or enthusiastic. They express the more or less negative or positive relationship to the social groups linked to these cultural forms (the working class, youth or migrants).

Public cultural policy can play a role in the making and the reproduction of these cultural classifications, as shown in my analysis of the making of 'culture' as a specific policy category in France (Dubois, 1999). In that book, I tried to show how contemporary state cultural policy has been invented, shaped and institutionalised, from the end of the nineteenth century to the end of the twentieth. An important question was how the borders of cultural policy were established, what definition of culture prevailed, what kind of cultural activities were included or excluded. In this process of inclusion and exclusion which defined the proper domain of cultural policy and provided the official definition of what culture is and is not, 'low' culture was of course a key issue'. The reflections presented here are based on this earlier work and on more recent research on the way French cultural policies deal with 'folk', 'popular' or 'minor' forms of culture.

\footnotetext{
${ }^{1}$ I will use the terms low or lowbrow culture rather than popular culture for linguistic and conceptual reasons explained in the first part of this paper.
} 


\section{Questions of definition}

I will start with the standard question of definitions. This question must especially be raised in a paper dealing with France since the literal translation into French of the phrase 'popular culture' (cultures populaires, most often used in the plural) is polysemous, controversial and has even more general and various connotations than the English term which is itself ambiguous (Storey, 2006). My point is not to discuss what would be the best definition of cultures populaires but to briefly underline the competing or overlapping definitions used in cultural policy institutions and debates.

Three main meanings can be distinguished from this point of view. The first is perhaps the closest to the English sense of popular culture as mass culture, or culture disseminated widely by the cultural industries and the media. In the 1960s 'mass culture' was often used in policy discourse, almost always in a negative sense. The Ministry of Cultural Affairs used it in contrast with 'real' culture, that is to say high culture. Governmental cultural policy was at this time supposed to propose an uplifting alternative to mass culture, which was considered facile and 'inauthentic'. Malraux refused to use the phrase culture populaire and explained: 'Culture is popular because of those it reaches and not because of its nature' ${ }^{2}$. That is to say: there is no 'popular culture' defined by its content, but culture (narrowly defined as the consecrated forms of heritage and art) can become 'popular' when it is spread among the people, especially among the sizeable working class. This was a direct answer to those, on the left and especially among fractions of the Communist Party, who claimed to promote culture populaire defined as the cultural expression of the working class. As for left-wing politicians and cultural policy entrepreneurs, they also denounced mass culture as numbing the minds of the working class, in contrast with 'authentic' folk culture and/or the emancipation achieved through access to the so-called universal classical culture. Culture de masse sounds a little old fashioned nowadays. More commonly used today is the expression 'commercial culture', which evokes the aesthetically and politically dubious products of entertainment companies. It can sound insulting to artists, professionals or policy makers in the cultural sector, because of the opposition it implies between art and money structuring it (Bourdieu, 1996).

\footnotetext{
${ }^{2}$ (Tranlated by the author) : 'La culture est populaire par ceux qu'elle atteint, non du fait de sa nature' (Speech to the Assemblée nationale, 1966).
} 
Once again most cultural policy programmes are implicitly or explicitly designed in opposition to these forms of 'popular culture'.

The second meaning is more general and also more often used. Culture populaire is in this case opposed to learned culture, in the same way as low, non-institutional or amateur are opposed to high, institutional and professional. Cultural policy and above all state cultural policy has contributed to the institutionalisation of such distinctions. Since its creation in 1959 the Ministry of Culture has mostly been the department for professional artists: amateur cultural practices have been taken into account only rarely and recently. More generally it was mostly concerned with high culture; what Malraux called the masterpieces of world heritage. An official separation was made at the beginning of the 1960 s between culture with a capital C (the exclusive focus of governmental cultural policy) and 'intermediate' or 'everyday' forms of culture, handled under rubrics such as animation socio-culturelle or éducation populaires and left to associations, local authorities and to the Department of Youth and Sports (Dubois, 1999; Urfalino, 1996). This hierarchical separation was incarnated in the distinction between the Maisons de la Culture launched by Malraux and the Maisons des Jeunes et de la Culture (MJC) created after the Second World War under the authority of the department of youth and sports. The former were managed by professional artists, were intended to bring 'the highest forms of culture' to the people and were called 'cathedrals of culture'. The $M J C$, on the other hand, were multipurpose establishments with social and educational activities and progressively included specifically cultural ones ${ }^{3}$.

Governmental cultural policies later contributed to a reconsideration of this hierarchical distinction. This was primarily the case in the 1980s during Jack Lang's Ministry (Looseley, 1995: 113-134; Dubois, 1999: 278-298). In this context, cultures populaires refers to positive and sometimes mythical aspects like spontaneity, authenticity, links to real life, and in fact everything that elites view as a kind of popular 'paradise lost'. The purpose of cultural policy in this case was to allow these cultural forms to be regarded as valuable when they usually were not. Most of the ambiguities and contradictions of cultural policy stem from these two faces of cultures populaires, alternately despised because they are not regarded as 'real'

\footnotetext{
${ }^{3}$ On the history of the Maisons des Jeunes et de la Culture and the evolution of their activities towards culture, see Besse, 2008.
} 
culture, or integrated in a flagship policy programme in order to restore the dignity policy makers think such cultures deserve.

Finally, cultures populaires can be defined in social terms, that is, referring to the culture of a specific social group. This can include youth culture or the culture of minorities such as migrants or even local culture. This social definition of culture is a broad one, which can include folk art, traditions and lifestyles. We will see that it is sometimes related to specific cultural policies oriented towards the preservation of an 'ethnographic heritage' or towards 'social integration'. Once again it has much to do with the definition of the boundaries of cultural policy itself. Above all the social definition of cultures populaires refers to the culture of the working class (culture ouvrière). Here the political issue is the representation of this class, claimed for instance by the French Communist Party's cultural programmes between the two world wars and during the 1950's. Even in that case, however, there is still a hesitation between culture ouvrière as proletarian culture, expected to replace bourgeois culture in revolutionary mode, and the goal of giving the workers access to culture (even to bourgeois culture) in a perspective of social emancipation.

These uncertainties over definition are not only conceptual ones. They also reveal cultural and political issues and conflicts certainly not specific to France but which are, or were, particularly important in that country. The main points in these issues and conflicts can be summed up in the following general questions raised in cultural policies and politics. How is culture in general to be defined, and who has the authority to define it? And then: what deserves public support? The question here is whether cultural policy must only confirm and reproduce the dominant definition of cultural value or whether it has a proactive role to play in this definition and its evolution. What is or should be the relationship between culture and the people, and how should it be organised? Are the people defined by their need to be 'educated' and 'elevated' or by their participation in cultural creation? Before showing how these rather abstract interrogations are involved in very concrete questions, I will recall some of the main characteristics of French cultural policy determining the way this policy has addressed them.

\section{French cultural policy $v s$. low culture: some determining factors}


The determining role played in France by cultural policies and by public institutions in cultural life in general gives them an important place in the processes of cultural legitimation ${ }^{4}$. As Raymonde Moulin has shown, cultural officials can have a strong influence in the consecration of artists (Moulin, 1992). More generally they act as gate-keepers certifying what culture is valued, or what can and cannot be regarded as 'real' culture. 'Artistic counsellors' (conseillers artistiques) working within the local services of the Ministry of Culture, for instance (directions régionales des affaires culturelles), claim to have a labelling function of this kind, which can have direct consequences on professional recognition and on access to public and private support. If we move on to a more general level we can say that cultural policies in France play an important symbolic role in the social representations of culture: to put it bluntly, what is regarded as 'culture' is what gets the support of the Ministry of Culture.

This symbolic power is centralised. Despite the decentralisation reforms initiated in the 1980s, Paris continues to dominate not only the administrative and political fields but also the cultural field (Menger, 1993). The fact that not only the Ministry but most of the major cultural institutions, and almost all national publishers and newspapers, in other words almost all of the cultural legitimation authorities, are based in Paris reduces the chances of recognition for specific or local cultures. The 'legitimism' (Bourdieu, 1984) of French culture and of French cultural policy, that is to say the socially determined 'truth' that there is no culture outside elite culture, has much to do with this centralisation.

As we have just seen, the Ministry of Culture has played an important role in this centralism and legitimism. It still does, even if things have changed since its creation. We have to keep in mind that this department was separated from the Ministry of Education, as well as from sports, leisure and popular education, so that it could concentrate on fine arts and heritage. This intellectual and institutional specification, together with the founding opposition to entertainment and the commitment to the 'democratisation of culture' focused state cultural policy on culture with a capital C. And popular culture has mostly been seen through the lens

\footnotetext{
${ }^{4}$ To avoid any misunderstanding I have to specify the way I use the notion of cultural legitimacy. Here I will remain faithful to Bourdieu's classic analyses, which do not define the legitimacy of a cultural good according to its aesthetic contents but as the result of the legitimation process consisting in the production of its cultural value by 'the legitimate agents of legitimation' of the cultural field (e.g. art critics, curators, experts, cultural experts or institutions, etc.). As a result when I describe popular cultures of one kind or another as 'illegitimate' I do not mean that they are illegitimate per se but only that they have not been consecrated through this symbolic selection process.
} 
of this institutional and elite definition of culture. Local authorities have mainly followed this legitimist orientation (Friedberg, Urfalino, 1986).

Another characteristic important to bear in mind is that public intellectuals play or at least have played an important role in cultural policy debates in France (Ahearne, 2004; 2010). As Pierre Bourdieu would put it, 'culture' is the topic par excellence of intellectual debates, and the 'popular' is an important issue in the struggles among intellectuals who claim to know what 'the people' is, what they need or what is good for them (Bourdieu, 1983). As a consequence most of the different kinds of intellectuals have a position on popular culture. Humanists want to enlighten the people through culture, paternalists provide vulgarised culture to vulgar people, populists and revolutionaries dream of reversing the social, political and cultural order, professional experts give advice to cultural policy makers, and conservatives aim to preserve 'real culture' from dilution and barbarian invasions (Fumaroli, 1991).

In this connection, the popular culture question has also been debated in the political field. The Right and Far-Right sometimes use this theme, to promote traditional values through 'grassroots', 'authentic' or local cultures, or to condemn the so-called cultural establishment which is deemed to be ruled by leftists (Dubois and Matz). But this conservative populism is less important to cultural policy than the debates on culture populaire within the Left. Briefly, left-wing cultural populism has always failed in French cultural policies, for diverse reasons. In the mid-1930s the Communist Party quickly abandoned the implementation of the class struggle model in favour of the promotion of humanism and national cultural heritage opposed to fascism (Péru, 1991; Ory, 1994). Workerism did not totally disappear, but there was not much social realism in France and communist cultural policies implemented by the Party and municipalities have followed the classical pattern of providing high culture to the people rather than replacing high culture by working class culture (Lambert and Matonti, 1998). In the late 1960s and 1970s, at local level, non-communist left-wing cultural policy for culture populaire was oriented towards everyday culture, neighbourhoods, creativity for all and so on. But it was soon abandoned with Lang's artist-centred policy in the 1980s, and replaced by the previously mentioned policy of cultural promotion. Let us turn now to these changing policy strategies in this field.

\section{Policies towards low culture: strategies and ambiguities}


It would be possible to identify general trends and patterns. For example, cultural policies have attached more importance to popular culture since the beginning of the 1980s; theatre and visual arts policies are more legitimist than dance and music policies; state institutions tend to promote elite culture in the name of aesthetic quality, whereas local authorities can sometimes be more opened to intermediate forms of culture, in the name of proximity or local traditions. But to do so would be far too simple and sometimes misleading. I would modestly suggest only two general rules. First it seems very difficult to find cultural policies that really break from a legitimist point of view, that is to say handling popular culture without referring it to high culture. Second, policy programmes designed for popular forms of culture usually mix together different logics and goals, which often contradict each other. In order to make it as clear as possible, I will present five attitudes or strategies as five ideal-types, knowing that in concrete policies these types often merge. These propositions are partly inspired by the work of Jean-Claude Passeron (Passeron, 1991).

The first and perhaps most frequent attitude is ignorance and neglect. Until the 1980s state cultural policy considered popular culture mostly in a negative way, as not worthy of public support. This remains partly true. Venues for rock music can get public support but are mainly self-funded, whereas opera houses and classical music institutions such as the Opéra National de Paris get around $70 \%$ of their budget from subsidies. Moreover 'popular' as well as 'folk' cultures are often still regarded as fake culture by cultural officials, the goal of cultural policy being to divert people from it. This s still true of amateur music such as brass bands for instance: when I asked him about the difficulties being experienced by brass bands, the local advisor for music at the Ministry of Culture simply replied 'who cares? Let them die. They are community arts ['c'est de la tradition locale'] and not our business.' (Dubois, Méon, Pierru, 2009).

There is also an indirect proselytising strategy: using popular culture as a lure to lead people to high culture, or at least to cultural institutions where they would not go otherwise. For instance, programming a hip-hop show in an opera-house (Lafargue de Grangeneuve, 2003) or curating a graffiti exhibition in an art museum (Dubois, 1999: 282-292) can be conceived as a means of bringing youngsters from the suburbs to these places, with the hope they will come back more easily to see something else. Far from being a 'populist' orientation celebrating the virtues of those forms of 'urban art', this is an indirectly legitimist policy 
oriented towards elite culture, in which the temporary and selective invitation of noninstitutional forms of culture is seen as a concession in order to bring a 'new audience' to cultural institutions - or at least to show the providers of public subsidy that efforts are being made to attract this audience.

This symbolic manipulation of 'low' cultural forms is also at work in a third and more common attitude consisting in using these cultural forms for non-cultural purposes, which raises the question of the way cultural policy programmes are articulated with other policy fields. We can see for instance this non-cultural use in programmes aimed at tackling social problems by cultural means. Among many examples, the most important and recent one certainly is the use of cultural projects within the urban policy programme launched in the 1990s and named politique de la ville, (literally: 'city policy'), which is in fact a policy for underprivileged suburban areas (Kiwan, 2007). This urban cultural policy has many different aspects and orientations, from a soft form of social control of idle youths to the promotion of citizenship; from the promotion of ethno-cultural diversity to the celebration of 'urban cultures'. At the beginning of the 1990s the programme for local rock venues was launched in a plan for 'urban social development' (développement social urbain) viewing it as a positive activity for youngsters in deprived neighbourhoods; it was not launched in an arts policy perspective viewing French local rock bands as valuable from a musical point of view and deserving public support for that reason (Brandl, 2009: 50-51). More recently hip-hop has become the 'cultural signature' of urban programmes (Faure, Garcia, 2005; Lafargue de Grangeneuve, 2008). There are also attempts to promote its aesthetic value (see below). But most of the time these programmes deal with hip-hop just as they would do with football or with a trip to the countryside: as a way of keeping young people busy, of re-socialising them and of giving them a chance to escape the routine of suburban life at least for an afternoon. But in return it also has symbolic effects which can be in contradiction with cultural rehabilitation, reproducing the stereotyped representation of hip-hop as an activity related to underprivileged teenagers often issued from migrant parents rather than just as an enjoyable and interesting kind of dance. Here the question is: is cultural promotion still cultural promotion when it is organised for social and not cultural purposes? Or cannot a low or popular culture (such as 'urban culture') be regarded (also) for its content rather than (only) for the social functions it is supposed to fulfil? 
Although it is logically in contradiction with this 'manipulation' strategy, 'aesthetic promotion' in Richard Shusterman's sense often overlaps with it in practice (Shusterman, 1992). There are few applications of Shusterman's pragmatist aesthetics, looking from an artistic point of view at things that are generally not regarded as art or advocating for the aesthetic the value of what is usually regarded as low or folk art. But most often, this promotion is also a transformation. Hip-hop dance is again a good example. Its promotion in cultural policy programmes does not only transport it from the street to the stage. Professional choreographers include it in their choreographies, create new shows with it, use it as a source for art dance and reshape it so that it fits with the dominating aesthetic criteria. In the end hiphop is absorbed by a legitimate form of art more than it is promoted as an autonomous form of popular culture (Looseley, 2004, 2005). Aesthetic promotion is then denounced, by those who have not undergone these processes of institutionalisation ${ }^{5}$, as a cultural hijacking. Promotion policies for brass band music are another example (Dubois, Méon and Pierru, 2009: 251-268). Based on the acknowledgement of the fact that people usually look down on this music regarded as 'old-fashioned' if not 'bad taste', these policies do not try to show how it can be interesting from a historical and/or musical point of view. They implicitly acknowledge that it is old fashioned (when they call for a stylistic update), bad quality (when they encourage the hiring of professional conductors in order to 'improve the level'), or bad taste (when they advocate for a more 'demanding' repertoire). Contrary to aesthetic promotion as defined by Shusterman these policies do not constitute a plea for the cultural recognition of a folk form of music; they rather constitute an attempt to convert this music into a form that complies with the rules of the institutional music field.

This conversion policy can consist in the 'museification' and/or scientific objectification of cultural objects or activities. This fifth and last ideal-typical strategy is not at all a new orientation. We might think of folk literature in the eighteenth and nineteenth centuries (de Certeau, 1998), of the 'metropolitan ethnography' and the musée des arts et traditions populaires (the museum of folk arts and traditions) in the 1930's ${ }^{6}$. Here 'popular' (in the sense of folk) culture is mostly seen through the vision and interests of the elite. It is not a

\footnotetext{
${ }^{5}$ Because they have not been selected and/or because they adopt a 'countercultural' or 'underground' attitude rejecting any kind of institutionalisation.

${ }^{6}$ The national folklore programme under the Vichy regime is partly linked to these previous experiences (this is a highly controversial point) but with a different political meaning oriented towards the glorification of the 'real people' incarnating eternal France and the denunciation of the 'cosmopolitan elite' accused of being responsible for 'national decline' (Faure, 1989).
} 
living culture to be organised and promoted but rather a set of 'objects of curiosity' (in both the common and museographic senses of the term) to be displayed. Michel de Certeau referred to this interest as the 'beauty of the dead', arguing that in this perspective popular culture became worthy of attention only when it was disappearing, or had disappeared. Museification plays an active role in this process, by detaching culture from its environment, resulting in a symbolic taming. In this perspective we could say that curiosity kills part of the socio-political meaning and potentially subversive strength of cultures populaires defined as the history, lifestyles and mentalities of the lower classes. The policy of ethnographic heritage made by the Ministry of Culture is a good example of this neutralisation process. In France as in other countries it developed in the 1980s, a period of massive deindustrialisation. The conversion of mine shafts and blast furnaces into coal mining and steel industry museums in Northern France and Lorraine was a means of symbolic compensation for the last of generations of miners and steel workers (Tornatore, 2010); it has also become a symbol for the cynicism of a planned political abandonment of mass workers' employment. This ambiguity provides additional evidence that dealing with cultures populaires is also if not above all dealing with major social and political issues.

The so-called 'crisis' of the French cultural policy model (Dubois, 2011) is mainly based on the (questionable) 'failure' of cultural democratisation which, together with budget problems and the rise of new issues such as the funding of contract workers in the entertainment sector (les intermittents $d u$ spectacle) and the effects of the internet on cultural practices and copyright, has challenged the role of the Ministry of Culture. But it has not radically changed the structure of these official attitudes towards low culture. The five ideal-types I outlined remain relevant to describe the current situation, and they matter nowadays in concrete policy making in more or less the same way as they did at the beginning of the 1990s. This does not mean that nothing has changed since then. For various reasons the symbols of elite culture, especially in contemporary art and music, are increasingly debated (if not criticised) in the media and in the political field for getting large amounts of public money but attracting only a small or a 'snob' audience. In a context of financial austerity such criticisms may can encourage budget cuts for these art forms; but they hardly ever help more 'popular' culture to obtain more public support. In other words, challenging cultural legitimism in this context has more to do with the weakening of state cultural policy than with the readjustment of public support among cultural hierarchies. 
The evolution that has occurred since Nicolas Sarkozy's election as President of the Republic in 2007 is a good illustration of this orientation. With his connections in show business ${ }^{7}$, his pop singer wife, his omnipresence in the popular press, his statements on the pointlessness of classical culture or his remoteness from intellectual life, Nicolas Sarkozy projects the public image of a President who is closer to popular culture than his predecessors. This intentionally demonstrates his closeness to the economic fraction of the bourgeoisie (as opposed to the cultural fraction) rather than to the ordinary people and the lower classes. The cultural populism of this 'bling' culture' is above all a rejection of the 'cultural establishment', said to be mostly 'leftist'.

All of this has implications in terms of cultural policy, or at least in terms of policy discourse. The first (and until now main) cultural policy statement made by Nicolas Sarkozy was his letter to Christine Albanel when he appointed her as Minister of Culture in 2007. One of the points most commented on was his plan to involve non-professionals (i.e. representatives of the public) in commissions which award grants to artists, in order to satisfy the cultural expectations of the people ('les attentes $d u$ public') and not only the preferences of the cultural milieu. This plan has not been implemented but could be interpreted as the sign of a new orientation towards a 'market-driven populism' against contemporary artists and cultural professions, which could lead to a shift replacing the traditional cultural policy of 'supply' (providing the people with quality culture) with a new 'demand'-led policy (giving the people/consumers what they want). Similar comments can be made about the Council for Artistic Creation. This new institution was created in 2009 in competition with the Ministry of Culture, which was deemed to be unable to launch innovative cultural projects. As can be expected the members of the Council are directors of cultural institutions, higher civil servants, academics, journalists or artists: no representatives of the public here. The ongoing programmes of the Council do not deal with folk or 'low' forms of culture, but they tend to short-circuit the formal cultural institutions with an important use of the internet or a mobile school for cinema. Once again political criticism of 'institutional culture' challenges the cultural policy system (much to the satisfaction of the neoconservative electorate, which mainly comes from the economic bourgeoisie), with little effect on the actual distribution of public support to 'popular' forms of culture (and on the promotion of the lower classes).

\footnotetext{
${ }^{7}$ Such as the rapper Doc Gyneco or the comic Jean-Marie Bigard.
} 


\section{Conclusion}

The strong embeddedness of these questions in socio-political issues is fundamental for understanding the various ambiguities and paradoxes in the relationship between low culture and French cultural policy. This policy was launched at the beginning of the 1960s to unite people in a common admiration of elite art. This national communion (in the religious sense of the term) implied setting aside social and cultural divisions in the name of the celebration of a single (elite) culture. Social classes and especially the working class were taken into account as targets of the cultural democratisation programme, but there was no place for 'low' or 'popular' culture which was seen as a source of division and above all as 'dubious cultural goods' (to quote one of Malraux's higher civil servants), that the Ministry of Culture had to fight rather than promote. We cannot fully understand this cultural policy orientation without having in mind the historical context of the making of the Fifth Republic and the return of General de Gaulle as head of the state (Dubois, 1999, $155 s q$ ). Culture was a new field of intervention symbolising the government style that the new regime intended to incarnate, based on the authority of the state, the messianic programme of national and political grandeur and a charismatic relationship to the people. This historical context was also structured by the political and cultural strength of the Communist Party and its workerist and anti-bourgeois orientation at this time: the relationship between 'culture' and 'the people' was a political issue because it provided the occasion to express antagonist visions of society. If we think now of the second crucial period of state cultural policy in France, that is to say the beginning of the 1980s, the opening up of the definition of culture to new, 'minor', 'popular' or 'lower' forms of culture must also be placed in the context of a major political shift with the arrival of François Mitterrand and the Socialist Party to power in 1981. Once again culture was erected as a symbol for political change and a new vision of society. But this time 'low' culture was integrated into governmental 'cultural democracy' programmes to show a new general orientation towards youth, migrants or the disadvantaged.

We could go on with other examples but these two determining periods are enough to show that when cultures populaires are at stake we have to take political and social dimensions into account and not only cultural ones in the narrow sense of that term. This brings us to a first paradox: how a cultural policy mainly designed to promote elite culture against 'low' culture could come to deal with non-elite forms of culture. We have explored the various typical strategies in this field and seen that the aesthetic promotion of non-elite culture was most of 
the time caught up in the cultural hierarchies it intended to change. To end with a more normative statement, I would say that in an ideal world, the emancipation of low culture should be achieved starting from its specific values and $\operatorname{logics}^{8}$, rather than from the point of view of legitimate culture, which makes 'low' culture a dominated culture. This is not a populist statement, arguing that 'popular', 'folk' or 'low' cultures are self-sufficient, as valuable as high culture or even superior to it. Nor is it a definitive criticism of the handling of popular culture in French cultural policy. Rather, it is a reminder that we cannot think of the promotion of non-elite culture without placing it in the perspective of cultural domination, which is too often the case in cultural policy, and increasingly the case in cultural sociology.

\footnotetext{
${ }^{8}$ To paraphrase Marx's famous sentence 'The emancipation of the workers will be achieved by the workers themselves'.
} 


\section{References}

Ahearne, J., 2004. Between cultural policy and theory: the cultural policy thinking of Pierre Bourdieu, Michel de Certeau and Régis Debray. Coventry: Centre for cultural policy studies, University of Warwick, research paper no. 7.

Ahearne, J., 2010. Intellectuals, culture and public policy in France. Approaches from the left. Liverpool: Liverpool university press.

Besse L., 2008. Les MJC de l'été des blousons noirs à l'été des Minguettes, 1959-1981. Rennes: Presses universitaires de Rennes.

Bourdieu P., 1983. Vous avez dit 'populaire'? Actes de la recherche en sciences sociales, 46: 98-105.

Bourdieu, P., 1984. Distinction: a social critique of the judgement of taste. London: Routledge.

Bourdieu, P., 1996. Rules of Art: Genesis and Structure of the Literary Field, Stanford University Press.

Brandl E., 2009. L'ambivalence du rock: entre subversion et subvention. Une enquête sur l'institutionnalisation des musiques populaires. Paris: L'Harmattan.

De Certeau M., 1998. Culture in the plural. University of Minnesota Press.

Dubois V., 1999. La politique culturelle: genèse d'une catégorie d'intervention publique. Paris: Belin.

Dubois V., 2011. Le 'modèle français' et sa 'crise' : ambitions, ambiguïtés et défis d'une politique culturelle. In Saint-Pierre D., Audet C. (eds.), Tendances et défis des politiques culturelles: cas nationaux en perspective, Québec, Presses de l'université Laval (forthcoming).

Dubois V., Matz K., forthcoming. La politisation contre les politiques culturelles: retour sur les «affaires » culturelles. In Dubois V., Le politique, l'artiste et le gestionnaire, Broissieux: Croquant.

Dubois V., Méon J.-M., Pierru E., 2009. Les mondes de l'harmonie: enquête sur une pratique musicale amateur. Paris: La Dispute.

Faure S., Garcia M.-C., 2005. Culture hip-hop, jeunes des cités et politiques publiques, Paris: La Dispute.

Faure C., 1989. Le projet culturel de Vichy. Paris: PUF/CNRS.

Friedberg E., Urfalino P., 1986. La décentralisation culturelle au service de la culture nationale. In Moulin R. (ed.), Sociologie de l'art, Paris: La Documentation française, 23-30.

Fumaroli M. 1991. L'Etat culturel: essai sur une religion moderne, Paris: éditions de Fallois.

Kiwan N., 2007. When the cultural and the social meet: a critical perspective of socially embedded cultural policy in France. International Journal of Cultural Policy, 13 (2), 153-167. Lafargue de Grangeneuve L., 2003. L'Opéra de Bordeaux, la danse hip-hop et ses publics. In Le(s) public(s) de la culture. Politiques publiques et équipements culturels, Paris: Presses de Sciences Po, 343-357.

Lafargue de Grangeneuve L., 2008. Politique du hip-hop: action publique et cultures urbaines. Toulouse: Presses universitaires du Mirail.

Lambert B., Matonti F., 1998. Les 'Forains légitimes': élus communistes et metteurs en scène, histoire d'une affinité elective. In Dubois V. (ed.), Politiques locales et enjeux culturels. Paris: La Documentation française, 333-360.

Levine L., 1990. Highbrow, Lowbrow: the emergence of cultural hierarchy in America. Cambridge: Harvard University Press.

Looseley D., 1995. The politics of fun: cultural policy and debate in contemporary France. Berg: Oxford/New York. 
Looseley D., 2004. Popular music in contemporary France: Authenticity, politics, debate, Okford/New York : Berg Publishers.

Looseley D., 2005. The return of the social. Thinking postcolonially about French cultural policy. International Journal of Cultural Policy, 1 (2), 145-155.

Menger P.-M., 1993. L'hégémonie parisienne: économie et politique de la gravitation artistique. Annales. Histoire, sciences sociales, 48 (6), 1565-1600.

Moulin R., 1992. L'artiste, l'institution et le marché, Paris: Flammarion, 1992

Ory P., 1994. La Belle illusion: culture et politique sous le signe du Front populaire 19351938. Paris: Plon.

Passeron J.-C., 1991. Figures et contestations de la culture. Légitimité et relativisme culturel. In Le raisonnement sociologique, Paris: Nathan, 291-334.

Péru J.-M., 1991. Une crise du champ littéraire français: les débats sur la 'littérature prolétarienne' (1925-1935). Actes de la recherche en sciences sociales, 89, 47-65.

Shusterman R., 1992. Pragmatist Aesthetics: Living Beauty, Rethinking Art. Oxford: Blackwell.

Storey J., 2009. Cultural theory and popular culture. Pearson Education.

Tornatore J.-L., 2010. L'invention de la Lorraine industrielle. Paris: Riveneuve.

Urfalino P., 1996. L'invention de la politique culturelle. Paris: La Documentation française. 